\title{
MANEJO DEL ESTRÉS EN SITUACIONES ACADÉMICAS
}

\section{Iván BARRIOS ${ }^{1}$, Julio TORALES ${ }^{1}$}

\author{
${ }^{1}$ Universidad Nacional de Asunción, Facultad de Ciencias Médicas, San Lorenzo, Paraguay.
}

Cómo citar este artículo: Barrios I, Torales J. Manejo del estrés en situaciones académicas. Med. clín. soc. 2019;3(2):41-42.

Como bien sabemos los estudiantes de ciencias de la salud manifiestan mayores frecuencias de ansiedad, depresión y síndrome de Burnout $(1,2)$, lo cual deriva en niveles más elevados de estrés. Existen eventos que producen una exacerbación de dichos síntomas, como son por ejemplo las evaluaciones finales. Es en este contexto que se comparte algunas técnicas que pueden servir para aliviar dicho estrés.

Algunas de las estrategias que ayudan afrontar las manifestaciones en la fase de agotamiento del estrés son (3): Planificar actividades priorizando entre ellas, decidir entre diversas técnicas de estudio, alimentarse saludablemente en horarios estables, practicar deporte o actividades recreativas, dedicar tiempo a pasatiempos y hobbies, mantener ciclos de sueño estables, buscar ayuda y compartir con otros, practicar relajación y respiración profunda, mantener el sentido del humor, esforzarse en mantener la calma y tranquilidad.

El mindfulness es un método cognitivo que consiste en prestar atención plena al cuerpo, respiración, pensamientos, emociones, y conductas, que se utiliza para reducir el estrés, dolor, ansiedad y depresión, el cual cuenta con algunas evidencias clínicas (4).

Una investigación realizada por Dundas y colaboradores reportó que el mindfulness es útil para la reducción del estrés por evaluación académica, se encontró reducciones en los componentes cognitivos y emocionales de la ansiedad de la evaluación y esa reducción continuó después de la intervención (5), por lo que este tipo de terapia tiene evidencia y se puede recomendar su utilización, así como la relajación muscular progresiva de Jacobson.

Es fundamental que los estudiantes universitarios busquen algún tipo de ayuda o actividad que ayude a disminuir los niveles de estrés y ansiedad ante las evaluaciones académicas, puesto que pueden tener resultados negativos que contribuyan más al aumento del estrés y ansiedad.

\section{CONFLICTOS DE INTERÉS Y FUENTE DE FINANCIACIÓN}

Los autores declaran no poseer conflictos de interés. Fuente de financiación: ninguna.

\section{REFERENCIAS BIBLIOGRÁFICAS}

Autor correspondiente: Prof. Dr. Julio Torales (jtorales@med.una.py).

Manuscrito recibido: 30 de agosto de 2019. Manuscrito aceptado: 30 de agosto de 2019.

Esta obra está bajo una licencia de Creative Commons Reconocimiento 4.0 Internacional. 
1. Rojas-Melgarejo J, Mereles-Oviedo F, Barrios I, Torales J. Síndrome de Burnout en estudiantes de medicina de Santa Rosa del Aguaray. Med Clín Soc. 2017;1(1):26-30. $\underline{\text { URL. }}$

2. Barrios I, Miltos V, Piris A, Piris G, Ramírez C, Rodríguez J, et al. Tamizaje de salud mental mediante el test M.I.N.I. en estudiantes del ciclo básico de medicina de la Universidad Nacional de Asunción. An Fac Cienc Médicas Asunción. 2015;48(1):59-68. https://dx.doi.org/10.18004/anales/2015.048(01)59-068

3. Universidad de Chile. Reconocer, prevenir y afrontar el estrés académico. Univ Chile. URL.

4. Oblitas L, Soto D, Anicama J, Arana A. Incidencia del mindfulness en el estrés académico en estudiantes universitarios: Un estudio controlado. Ter Psicológica. 2019;37(2):116-28. URL.

5. Dundas I, Thorsheim T, Hjeltnes A, Binder PE. Mindfulness Based Stress Reduction for Academic Evaluation Anxiety: A Naturalistic Longitudinal Study. J Coll Stud Psychother. 2016;30(2):114-31. https://dx.doi.org/10.1080/87568225.2016.1140988 


\section{STRESS MANAGEMENT IN ACADEMIC SITUATIONS}

\section{Iván BARRIOS ${ }^{1}$, Julio TORALES ${ }^{2}$}

${ }^{1}$ Universidad Nacional de Asunción, Facultad de Ciencias Médicas, San Lorenzo, Paraguay.

How to cite this article: Barrios I, Torales J. Manejo del estrés en situaciones académicas. Med. clín. soc. 2019;3(2):41-42.

As we well know, students of health sciences manifest higher frequencies of anxiety, depression and Burnout syndrome $(1,2)$, which results in more severe levels of stress. There are events that produce an exacerbation of these symptoms, such as final evaluations. It is in this context that he shares some techniques that can be used to relieve such stress.

Some of the strategies that help to face the manifestations in the stress exhaustion phase are (3): Plan activities prioritizing among them, decide between divers and study techniques, eat healthily in stable schedules, practice sports or recreational activities, dedicate time to hobbies and hobbies, maintain stable sleep cycles, seek help and share with others, practice relaxation and deep breathing, maintain a sense of humor, strive to maintain calm and tranquility.

Mindfulness is a cognitive method that consists in paying full attention to the body, breathing, thoughts, emotions, behaviors, which is used to reduce stress, pain, anxiety and depression, which has some clinical evidence (4).

An investigation carried out by Dundas and collaborators reported that mindfulness is useful for the reduction of stress by academic evaluation, there were reductions in the cognitive and emotional components of the anxiety of the evaluation and that reduced reduction after the intervention (5), by what this type of therapy has evidence and its use can be recommended, as well as Jacobson's progressive muscle relaxation.

It is essential that university students seek some kind of help or activity that helps reduce stress and anxiety levels in the face of academic assessments, since they can have negative results that contribute more to the increase in stress and anxiety.

\section{CONFLICTS OF INTEREST AND FUNDING}

Conflicts of interest: none. Funding source: none.

\section{REFERENCES}


1. Rojas-Melgarejo J, Mereles-Oviedo F, Barrios I, Torales J. Síndrome de Burnout en estudiantes de medicina de Santa Rosa del Aguaray. Med Clín Soc. 2017;1(1):26-30. URL.

2. Barrios I, Miltos V, Piris A, Piris G, Ramírez C, Rodríguez J, et al. Tamizaje de salud mental mediante el test M.I.N.I. en estudiantes del ciclo básico de medicina de la Universidad Nacional de Asunción. An Fac Cienc Médicas Asunción. 2015;48(1):59-68. https://dx.doi.org/10.18004/anales/2015.048(01)59-068

3. Universidad de Chile. Reconocer, prevenir y afrontar el estrés académico. Univ Chile. URL.

4. Oblitas L, Soto D, Anicama J, Arana A. Incidencia del mindfulness en el estrés académico en estudiantes universitarios: Un estudio controlado. Ter Psicológica. 2019;37(2):116-28. URL.

5. Dundas I, Thorsheim T, Hjeltnes A, Binder PE. Mindfulness Based Stress Reduction for Academic Evaluation Anxiety: A Naturalistic Longitudinal Study. J Coll Stud Psychother. 2016;30(2):114-31. https://dx.doi.org/10.1080/87568225.2016.1140988 